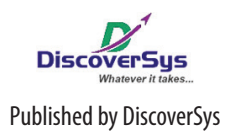

Published by DiscoverSys

\section{Direct and Indirect Factors Influencing Selection of Birthing Attendants in Gunungsari, West Lombok (NTB)}

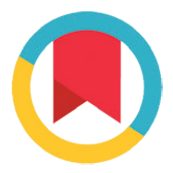

CrossMark

Ni Nyoman Aryaniti, ${ }^{1,4^{*}}$ Luh Putu Lila Wulandari, ${ }^{1,2}$ I Nyoman Mangku Karmayaa ${ }^{1,3}$

\section{ABSTRACT}

Background and purpose: This study aims to determine the direct and indirect factors influencing the selection of birth attendants in Gunungsari subdistrict, West Lombok.

Methods: This study was cross-sectional with a purposively selected sample of 27 mothers giving birth assisted by non-health professionals. Samples of those assisted by health professionals were taken by means of proportional systematic random sampling in Gunungsari and Penimbung health centers, respectively 29 of 916 and 14 of 437. Exogenous factors were maternal education levels, attendance to ANC classes, knowledge levels regarding to birthing attendants, maternal attitude, family support, and access to facilities. Birth attendant selection was the endogenous factor. Data were collected by means of interviews. Data analysis includes descriptive and inferential analysis with path analysis by linear regression.

Results: The majority of respondents were 21-25 years old (87.4\%), housewives (47.14\%) had education under high school (65.72\%) and were married (88.57\%). Family support had a direct influence in decision making with a coefficient of 0.534 and $35.54 \%$ influence overall. Attendance to ANC classes in addition to family support had an indirect influence with a coefficient of 0.520 and $34.78 \%$ influence overall. Family support had a direct influence and the factor of attendance to ANC classes and family support has an indirect effect with the overall effect of $70.32 \%$. Conclusion: The presence of the husband/family was needed in ANC class, through an implementation of schedule agreement.

Keywords: family support, ANC class, birth attendants, path analysis, West Lombok Cite This Article: Aryaniti, N.N., Wulandari, L.P.L., Karmaya, I.N.M. 2014. Direct and Indirect Factors Influencing Selection of Birthing Attendants in Gunungsari, West Lombok (NTB). Public Health and Preventive Medicine Archive 2(2): 102-108. D01:10.15562/phpma.v2i2.132

\title{
Pengaruh Langsung dan Tidak Langsung Beberapa Faktor terhadap Keputusan Pemilihan Penolong Persalinan di Kecamatan Gunungsari Lombok Barat
}

\section{ABSTRAK}

Latar belakang dan tujuan: Penelitian ini bertujuan untuk mengetahui faktor langsung dan tidak langsung yang mempengaruhi keputusan pemilihan penolong persalinan oleh ibu bersalin di Kecamatan Gunungsari Kabupaten Lombok Barat.

Metode: Penelitian menggunakan desain cross-sectional analitik. Sebanyak 27 ibu bersalin ditolong tenaga bukan kesehatan dipilih secara purposive. Ibu bersalin yang ditolong tenaga kesehatan diambil secara proportional systematic random sampling dari Puskesmas Gunungsari dan Puskesmas Penimbung, masing-masing sebanyak 29 dari 916 ibu bersalin, dan 14 dari 437 ibu bersalin. Faktor eksogen yang diteliti adalah pendidikan ibu, kelas ibu hamil, pengetahuan ibu, sikap ibu, dukungan keluarga, dan akses. Keputusan pemilihan penolong persalinan sebagai faktor endogen. Data dikumpulkan dengan wawancara menggunakan kuesioner. Data dianalisis secara deskriptif, dan dilanjutkan dengan analisis jalur menggunakan regresi linier. Hasil: Kebanyakan responden berusia 21-35 tahun (87,4\%), ibu rumah tangga (47,14\%), berpendidikan menengah ke bawah $(65,72 \%)$, dan kawin (88,57\%). Hanya dua faktor eksogen yang berpengaruh yaitu dukungan keluarga mempunyai pengaruh langsung dengan koefisien 0,534 dan pengaruh total $35,54 \%$. Kelas ibu hamil melalui dukungan keluarga mempunyai pengaruh tidak langsung dengan koefisien 0,520 dan pengaruh total $34,78 \%$. Total pengaruh langsung dan tidak langsung terhadap keputusan pemilihan penolong persalinan oleh ibu bersalin 70,32\%.

Simpulan: Kehadiran suami/keluarga diperlukan dalam kelas ibu hamil melalui suatu kesepakatan jadwal pelaksanaan.

\section{${ }^{*}$ Correspondence to:}

Ni Nyoman Aryaniti, Public Health

Postgraduate Program Udayana

University

ninyomanaryaniti@yahoo.com
Kata kunci: kelas ibu hamil, dukungan keluarga, penolong persalinan, analisis jalur, Lombok Barat

Kutip artikel ini: Aryaniti, N.N., Wulandari, L.P.L., Karmaya, I.N.M. 2014. Pengaruh Langsung dan Tidak Langsung Beberapa Faktor terhadap Keputusan Pemilihan Penolong Persalinan di Kecamatan Gunungsari Lombok Barat. Public Health and Preventive Medicine Archive 2(2): 102-108. DOI:10.15562/phpma.v2i2.132 


\section{PENDAHULUAN}

Salah satu paradigma baru kesehatan reproduksi adalah hak dan peran perempuan terhadap pemilihan tempat bersalin. Ibu bersalin yang memilih tenaga kesehatan sebagai penolong persalinan dapat mengurangi angka kematian ibu dan bayi (AKI dan AKB). Dalam millennium development goals (MGDs), derajat kesehatan suatu bangsa diukur dengan tiga indikator utama, yaitu angka kematian ibu (AKI), angka kematian bayi (AKB), dan usia harapan hidup (UHH). ${ }^{1}$

AKI di Indonesia sampai saat ini relatif masih tinggi yaitu sebesar 228 per 100.000 kelahiran hidup begitu juga untuk AKB sebesar 34 per 1000 kelahiran hidup (KH). ${ }^{1}$ Target yang ingin dicapai oleh pemerintah pada MDGs tahun 2015 yakni AKI 102 per $100.000 \mathrm{KH}$ dan AKB 17 per 1000 KH. Salah satu penyebab kematian ibu melahirkan di Indonesia adalah masih adanya kebiasaan bersalin yang ditolong oleh dukun bayi. ${ }^{2}$ AKI pada masa persalinan di Indonesia cukup tinggi antara lain disebabkan karena persalinan yang ditolong oleh tenaga yang tidak kompeten dalam bidang kebidanan. $^{3}$

Pemerintah Daerah Provinsi Nusa Tenggara Barat telah mencanangkan program gerakan percepatan penurunan AKI dan AKB yaitu gerakan Angka Kematian Ibu Menuju Nol (AKINO). ${ }^{4}$ Program percepatan ini didukung dengan pelaksanaan kelas ibu hamil di puskesmas, pengembangan desa siaga dan jaminan persalinan universal (jampersal).

Puskesmas Gunungsari dan Penimbung berada di Kecamatan Gunungsari yang merupakan salah satu kecamatan di Kabupaten Lombok Barat, Provinsi NTB. Pada dua wilayah kerja puskesmas tersebut telah dilaksanakan program jampersal yaitu biaya persalinan tidak dipungut di unit pelayanan kesehatan pemerintah, pengembangan desa siaga yaitu setiap desa ada poskesdes dan bidan desa, serta pelaksanaan kelas ibu hamil. Dengan pelaksanaan program-program tersebut, ternyata masih ada persalinan yang ditolong oleh tenaga bukan kesehatan. Di wilayah ini tercatat persalinan oleh tenaga bukan kesehatan di tahun 2012 sebanyak 18 orang $(0,87 \%)$ dan tahun 2013 sebanyak 9 orang $(0,43 \%) .^{5-6}$

Salah satu teori yang dapat digunakan untuk menjelaskan perilaku pemanfaatan layanan kesehatan adalah teori perubahan perilaku. Perubahan perilaku masyarakat dipengaruhi oleh tiga faktor yaitu faktor-faktor predisposisi (predisposing factors) yang terwujud dalam pengetahuan dari pendidikan formal, nilai-nilai, budaya serta beberapa karakteristik individu, sikap, dan keyakinan. Faktor-faktor pendukung (enabling factors) yang terwujud dalam lingkungan fisik dan ketersediaan fasilitas dan sarana kesehatan, tercapainya fasilitas serta ketrampilan yang berhubungan dengan kesehatan dan faktor-faktor pendorong (reinforcing factors) yang terwujud dalam dukungan keluarga, kerabat, teman, petugas kesehatan dan sebagainya. ${ }^{7}$

Penelitian tentang faktor-faktor yang berhubungan dengan keputusan memilih penolong persalinan pernah dilakukan tahun 2013 di Puskesmas Taliwang Kabupaten Sumbawa Barat Provinsi NTB. Penelitian tersebut mencari hubungan beberapa variabel yang diasumsikan berpengaruh secara langsung terhadap pemilihan penolong persalinan. ${ }^{8}$ Sedangkan penelitian ini tidak saja mencari kemaknaan hubungan, tetapi juga mengukur besar pengaruh secara langsung maupun tidak langsung beberapa faktor eksogen terhadap keputusan pemilihan penolong persalinan oleh ibu bersalin di Puskesmas Gunungsari dan Penimbung tahun 2014.

\section{METODE}

Rancangan penelitian yang digunakan yaitu cross-sectional analitik. Data dikumpulkan di Puskesmas Gunungsari dan Penimbung wilayah kerja Kecamatan Gunungsari bulan Pebruari sampai Maret 2014. Populasi penelitian adalah ibu bersalin yang ditolong tenaga bukan kesehatan tahun 2012/2013 sebanyak 27 orang dan ibu bersalin yang ditolong tenaga kesehatan tahun 2013 sebanyak 1.353 orang, yang tercatat di laporan PWS KIA Puskesmas Gunungsari dan Penimbung. Besar sampel ditentukan berdasarkan tingkat akurasi menggunakan rumus besar sampel dari $\mathrm{WHO}^{9}$ sehingga didapatkan 70 sampel. Jumlah ibu yang bersalin di tenaga bukan kesehatan tahun 2012/2013 sebanyak 27 orang semuanya diambil sebagai sampel sehingga sampel untuk ibu yang bersalin di tenaga kesehatan adalah $70-27=43$ orang yang diambil secara proportional systematic random sampling. Jumlah sampel ibu bersalin oleh tenaga kesehatan di Puskesmas Gunungsari sebanyak 29 sampel dari 916 populasi ibu bersalin dan di Puskesmas Penimbung sebanyak 14 sampel dari 437 populasi ibu bersalin. Pertimbangan pengambilan semua ibu bersalin di tahun 2012/2013 sebanyak 27 orang karena keterbatasan jumlah ibu bersalin di tenaga bukan kesehatan. Sedangkan pengambilan sampel ibu bersalin oleh tenaga kesehatan hanya tahun 2013 karena kemiripan karakteristik ibu bersalin dan untuk lebih memudahkan pencarian sampel terpilih.

Selain karakteristik demografi (umur, pekerjaan, pendidikan, status perkawinan), variabel yang diukur 
adalah keputusan pemilihan penolong persalinan sebagai faktor endogen, sedangkan pendidikan ibu, kelas ibu hamil, pengetahuan ibu, sikap ibu, dukungan keluarga, dan akses sebagai faktor eksogen. Faktor kelas ibu hamil digali dengan 5 pertanyaan dan 1 data sekunder. Informasi yang digali adalah jumlah kehadiran, status pendampingan suami/keluarga, kepuasan terhadap materi pelajaran dan cara penyampaian oleh fasilitator, serta pemahaman ibu bersalin terhadap materi. Faktor pendidikan ibu ada 6 item pertanyaan meliputi jenjang pendidikan formal (tingkat pendidikan yang ditamatkan), pendidikan bukan formal (kursus/pelatihan-pelatihan yang pernah diikuti) dan pendidikan informal ibu (peran aktif ibu dalam kegiatan kemasyarakatan yang berkaitan dengan kesehatan). Faktor dukungan keluarga sebanyak 13 item pertanyaan, meliputi jumlah anak laki-laki, perencanaan persalinan, pekerjaan, pengambilan keputusan dalam rumah tangga, dukungan suami dan keluarga, baik pada saat hamil, rencana persalinan, dan persiapan persalinan. Faktor akses ke pelayanan kesehatan digali dengan 6 item pertanyaan, yaitu jarak, lama waktu, dan biaya untuk mencapai fasilitas/tempat pelayanan kesehatan terdekat. Faktor pengetahuan ibu dibentuk dari 9 item pertanyaan tentang pertolongan persalinan. Faktor sikap terdiri dari 6 item pertanyaan yang menunjukkan respon ibu terkait pertolongan persalinan. Faktor endogennya yaitu penolong persalinan dikategorikan menjadi nakes dan bukan nakes.

Pengumpulan data untuk faktor eksogen dilakukan dengan wawancara berpedoman pada kuesioner dengan skala Likert tiga opsi jawaban yakni, jawaban $A=5, B=3, C=1$. Dari seluruh pertanyaan pada masing-masing faktor kemudian jawabannya dijumlahkan. ${ }^{10}$ Sebelum dipergunakan sebagai alat pengumpul data, kuesioner telah diuji validitas dan reliabilitas dengan Cronbach's Alpha dimana nilai $\mathrm{r}$ hitung $>\mathrm{r}$ tabel ${ }^{11}$ dan didapatkan hasil $r$ hitung $>0,602$. Analisis univariat dilakukan untuk melihat distribusi frekuensi karakteristik responden. Uji statistik dilakukan untuk mengetahui besarnya pengaruh faktor secara langsung dan tidak langsung dipergunakan analisis jalur. Untuk kepentingan analisis pada analisis jalur maka seluruh jawaban pertanyaan dari masing-masing faktor eksogen dijumlahkan dan dikonversi dengan Method of Succesive Intervals (MSI) menjadi data dengan skala interval. ${ }^{11}$ Data yang sudah berskala interval kemudian dianalisis dengan regresi linier, dimana nilai standardized coefficients merupakan koefisien masing-masing jalur. ${ }^{12}$ Untuk dapat mengetahui kuat lemahnya tingkat atau derajat keeratan hubungan antara faktor eksogen dan faktor endogen berdasarkan
Tabel 1. ${ }^{11}$ Pengujian kebermaknaan jalur secara sendiri-sendiri dipergunakan uji t $(\alpha=0,05)$ dan kebermaknaan jalur secara keseluruhan dipergunakan uji $\mathrm{F}(\alpha=0,05)$.

Penelitian ini mendapat kelaikan etik dari Komisi Etik Penelitian Kesehatan Fakultas Kedokteran Universitas Mataram.

\section{HASIL}

Semua responden dapat berpartisipasi dengan baik dan tidak ada yang menolak. Karakteristik responden penelitian di Puskesmas Gunungsari dan Penimbung tahun 2013 disajikan pada Tabel 2. Sebagian besar responden adalah usia 21-35 (61; $87,14 \%)$, ibu rumah tangga $(33 ; 47,14 \%)$, tamat SD (24; 34,29\%), dan berstatus kawin (62; 88,57\%).

Hasil analisis jalur seperti pada Gambar 1, terlihat ada empat jalur yang mempunyai pengaruh masing-masing faktor terhadap faktor lainnya. Pendidikan memiliki koefisien 0,248 terhadap pengetahuan, artinya pengaruhnya lemah untuk terbentuknya pengetahuan ibu. Kelas ibu hamil memiliki koefisien 0,746 terhadap pengetahuan ibu, artinya pengaruhnya kuat untuk terbentuknya pengetahuan ibu. Kelas ibu hamil memiliki koefisien 0,975 terhadap dukungan keluarga, artinya pengaruhnya sangat kuat untuk terbentuknya dukungan keluarga yang positif. Pengaruh dukungan keluarga memiliki koefisien 0,534 terhadap pemilihan penolong persalinan, artinya pengaruhnya cukup terhadap pemilihan penolong persalinan. Selain empat jalur tersebut, terdapat juga empat jalur yang tidak mempunyai pengaruh masing-masing faktor terhadap faktor lainnya. Faktor tersebut adalah pengetahuan terhadap sikap, dukungan keluarga terhadap sikap, sikap ibu terhadap pemilihan penolong persalinan serta akses terhadap pemilihan penolong persalinan, dimana empat jalur tersebut tidak ada pengaruh yang signifikan. Besarnya koefisien jalur yang mempunyai pengaruh langsung maupun tidak langsung, serta persentase besarnya pengaruh masing-masing faktor terhadap pemilihan penolong persalinan disajikan dalam Tabel 3.

Tabel 3 menunjukkan faktor dukungan keluarga mempunyai pengaruh langsung dengan koefisien 0,534 dan sumbangan efektif dari jalur ini sebesar $35,54 \%$. Faktor yang berpengaruh tidak langsung yakni kelas ibu hamil melalui dukungan keluarga dengan koefisien 0,520 dan sumbangan efektif dari jalur ini sebesar $34,78 \%$. Dengan demikian total pengaruh langsung dan tidak langsung beberapa faktor terhadap keputusan pemilihan penolong persalinan mempunyai besaran pengaruh $35,54 \%+$ $34,78 \%=70,32 \%$. 
Tabel 1 Tingkat keeratan hubungan faktor eksogen dan endogen

\begin{tabular}{ll}
\hline Nilai korelasi & Keterangan \\
\hline $0,00-<0,20$ & Hubungan sangat lemah (diabaikan, dianggap tidak ada) \\
$\geq 0,20-<0,40$ & Hubungan rendah \\
$\geq 0,40-<0,70$ & Hubungan sedang/cukup \\
$\geq 0,70-<0,90$ & Hubungan kuat/tinggi \\
$\geq 0,90-\leq 1,00$ & Hubungan sangat kuat/tinggi \\
\hline
\end{tabular}

Tabel 2 Distribusi frekuensi responden di Puskesmas Gunungsari dan Penimbung tahun 2014

\begin{tabular}{lccc}
\hline & Tenaga kesehatan & Bukan tenaga kesehatan & Total \\
\cline { 2 - 4 } Karakteristik responden & $(\mathbf{n}=\mathbf{4 3})$ & $(\mathbf{n = 2 7})$ & (\%) \\
\hline Kelompok umur & & & \\
$\quad<20$ tahun & 0 & 5 & $5(7,14)$ \\
$21-35$ tahun & 39 & 22 & $61(87,14)$ \\
$\quad>35$ tahun & 4 & & $4(5,72)$ \\
Pekerjaan & & 0 & \\
$\quad$ PNS/pegawai swasta & 6 & 0 & $6(8,57)$ \\
Buruh & 4 & 5 & $4(5,71)$ \\
Pedagang & 10 & 20 & $15(21,43)$ \\
Ibu rumah tangga & 13 & 2 & $33(47,14)$ \\
$\quad$ Lainnya & 10 & & $12(17,15)$ \\
Pendidikan & & 12 & $12(17,14)$ \\
Tidak sekolah/tidak tamat SD & 0 & 15 & $24(34,29)$ \\
Tamat SD & 9 & 0 & $10(14,29)$ \\
SMP/sederajat & 10 & 0 & $8(11,43)$ \\
SMA/sederajat & 8 & 0 & $16(22,85)$ \\
Perguruan tinggi & 16 & & $62(88,57)$ \\
Status perkawinan & & 25 & $8(11,43)$ \\
Kawin & 37 & 2 & \\
Janda & 6 & &
\end{tabular}

Tabel 3 Pengaruh langsung dan tidak langsung beberapa faktor terhadap pemilihan penolong persalinan di Kecamatan Gunungsari tahun 2014

\begin{tabular}{lccccc}
\hline & \multicolumn{2}{c}{ Koefisien jalur } & & & \\
\cline { 2 - 5 } $\begin{array}{l}\text { Jalur hubungan } \\
\text { variabel }\end{array}$ & $\begin{array}{c}\text { Pengaruh } \\
\text { langsung }\end{array}$ & $\begin{array}{c}\text { Pengaruh } \\
\text { tidak } \\
\text { langsung }\end{array}$ & $\begin{array}{c}\text { Koefisien jalur } \\
\text { total } \\
\text { (a) }\end{array}$ & $\begin{array}{c}\text { Zero order } \\
\text { correlation } \\
\text { (b) }\end{array}$ & $\begin{array}{c}\text { Sumbangan efektif } \\
\text { (pengaruh total/\%) } \\
\text { (a x b) }\end{array}$ \\
\hline $\begin{array}{l}\text { Dukungan keluarga } \rightarrow \\
\text { pemilihan penolong } \\
\text { persalinan }\end{array}$ & 0,534 & - & 0,534 & 0,6656 & 35,54 \\
$\begin{array}{l}\text { Kelas ibu hamil } \\
\text { melalui dukungan } \\
\text { keluarga } \rightarrow \text { pemilihan } \\
\text { penolong persalinan }\end{array}$ & - & $0,975 \times 0,534$ & 0,520 & 0,6689 & 34,78 \\
\begin{tabular}{l} 
Pengaruh total \\
\hline
\end{tabular} & & & & & \\
\hline
\end{tabular}




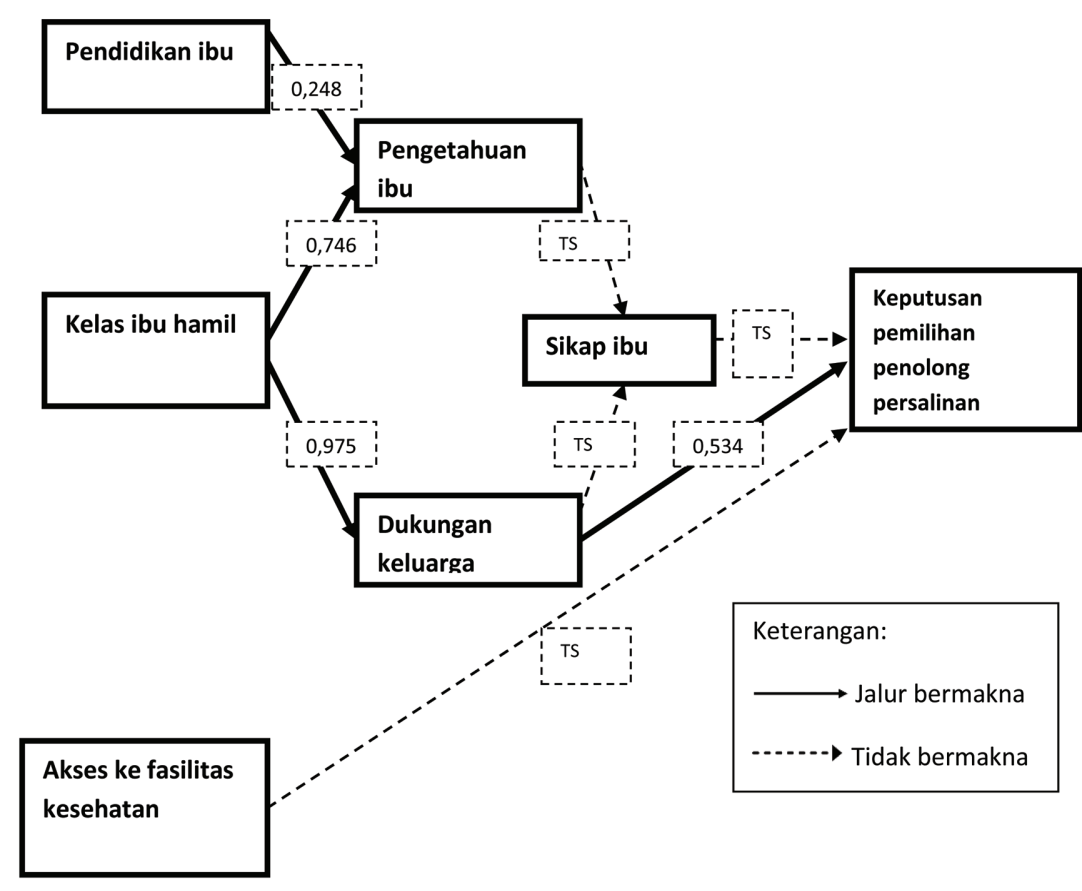

Gambar 1 Diagram analisa jalur pemilihan penolong persalinan

Faktor yang tidak mempunyai pengaruh secara langsung terhadap keputusan pemilihan penolong persalinan yaitu faktor akses, dan sikap ibu. Faktor yang tidak mempunyai pengaruh tidak langsung yaitu pendidikan melalui pengetahuan dan sikap ibu, kelas ibu hamil melalui pengetahuan dan sikap ibu, kelas ibu hamil melalui dukungan keluarga dan sikap ibu.

\section{DISKUSI}

Pada penelitian ini, dari enam faktor eksogen yang diduga mempunyai pengaruh terhadap keputusan pemilihan penolong persalinan, hanya dua faktor yang terbukti. Faktor dukungan keluarga berpengaruh langsung dan faktor kelas ibu hamil melalui dukungan keluarga mempunyai pengaruh tidak langsung.

Penelitian tentang pemilihan penolong persalinan pernah dilakukan di Desa Banjarsari Kabupaten Magelang tahun 2010yang menunjukkan bahwa 55,6\% ibu memilih pertolongan persalinan oleh dukun bayi dan $44,4 \%$ oleh bidan. ${ }^{13}$ Penelitian lain di Uganda tahun 2011 juga menunjukkan bahwa dukun bayi masih membantu perempuan untuk melahirkan di desa-desa dan berperan penting dalam kesehatan banyak ibu, memberikan perawatan yang baik bagi perempuan. ${ }^{14}$

Faktor dukungan keluarga mempunyai pengaruh langsung terhadap keputusan pemilihan penolong persalinan oleh ibu bersalin dengan koefisien jalur total sebesar 0,534. Koefisien 0,534 menunjukkan bahwa dukungan keluarga mempunyai pengaruh yang cukup. Hal ini berarti bahwa dukungan positif dari keluarga terhadap permasalahan seputar persalinan akan membuat keputusan yang positif dalam keputusan pemilihan penolong persalinan oleh tenaga kesehatan. Hasil penelitian ada 5 orang ibu bersalin berusia kurang dari 20 tahun yang ditolong oleh tenaga bukan kesehatan. Sedangkan 12 orang ibu bersalin lainnya berusia antara 21 sampai 25 tahun. Kenyataan ini sesuai dengan teori yang menyatakan bahwa perempuan usia muda cenderung masih bergantung kepada suami dan keluarga karena tingkat kemandiriannya rendah dalam hal mengambil keputusan, termasuk dalam hal pemilihan penolong persalinannya. Orang yang lebih tua dianggap lebih berpengalaman sehingga dapat memberikan pilihan yang terbaik. Dengan mengikuti saran orang tua, maka tanggungjawab terhadap situasi yang dihadapi menjadi beban bersama pelaku, keluarga dan orang tua..$^{15}$ Sumbangan efektif dari jalur ini, yang artinya secara sendiri faktor dukungan keluarga mempunyai pengaruh sebesar $35,54 \%$ terhadap keputusan pemilihan penolong persalinan oleh tenaga kesehatan. Kenyataan tersebut sejalan dengan beberapa hasil penelitian yang menyatakan bahwa alasan ibu bersalin memilih penolong persalinan oleh tenaga kesehatan yang terbanyak karena dukungan keluarga atau suami. ${ }^{16-18}$

Faktor kelas ibu hamil mempunyai pengaruh tidak langsung terhadap keputusan pemilihan penolong persalinan melalui dukungan keluarga dengan koefisien jalur total sebesar 0,520. Hal ini menunjukkan bahwa faktor kelas ibu hamil melalui dukungan keluarga akan membuat keputusan yang positif dalam memutuskan pemilihan penolong persalinan. Hal ini sesuai dengan tujuan dari pelaksanaan kegiatan kelas ibu hamil dimana ibu bertemu dan belajar bersama, pengetahuan dan keterampilan ditingkatkan untuk mengubah perilaku (pengetahuan, sikap, dan tindakan) ibu hamil dan keluarganya tentang berbagai hal yang menyangkut kehamilan dan persalinan. ${ }^{19}$ Sumbangan efektif dari jalur ini yang artinya secara sendiri faktor kelas ibu hamil melalui dukungan keluarga mempunyai pengaruh sebesar $34,78 \%$ terhadap keputusan pemilihan penolong persalinan oleh ibu bersalin untuk ditolong oleh tenaga kesehatan. Penelitian oleh Sari tentang keikutsertaan ibu dalam kelas ibu hamil di Padang dari 38 orang terdapat 21 orang $(55,3 \%)$ ibu hamil dengan dukungan suami tinggi, dan ada hubungan antara dukungan suami dengan keikutsertaan ibu dalam kelas ibu hamil. ${ }^{20}$ Penelitian lain tentang pelaksanaan kelas ibu hamil terkait dengan pemilihan penolong persalinannya di Kabupaten 
Kebumen menunjukkan hasil dari 119 responden 95,8\% memilih tenaga kesehatan sebagai penolong persalinannya. Pengambil keputusan dan dukungan peserta kelas ibu hamil juga mempunyai hubungan bermakna. ${ }^{21}$ Di daerah penelitian ada 48 orang $(68,57 \%)$ suami/keluarga yang ikut mendampingi ibu hamil dalam pelaksanaan kelas ibu hamil yang diselenggarakan oleh puskesmas. Dengan mengikuti penuh seluruh sesi pelaksanaan kelas ibu hamil dan ditambah dengan mengajak suami/keluarga, dapat meningkatkan pengetahuan tentang persalinan yang dapat ditularkan kepada keluarga yang lain sehingga pemahaman keluarga tentang berbagai hal persalinan terutama risiko persalinan akan semakin baik. Hal ini sejalan dengan gambaran hasil pelaksanaan kelas ibu hamil di Kota Semarang bahwa ibu hamil lebih mengetahui bahaya/risiko saat kehamilan dan mempunyai perencanaan persalinan yang dibantu oleh tenaga kesehatan..$^{22}$

Keterbatasan dalam penelitian ini adalah populasi ibu bersalin yang dijadikan sampel yaitu populasi tahun 2013. Sedangkan pengambilan sampel ibu bersalin ditolong oleh tenaga bukan kesehatan diambil secara keseluruhan dari total ibu bersalin di tolong tenaga bukan kesehatan tahun 2012 dan 2013. Pengambilan populasi ibu bersalin diambil hanya pada tahun 2013 karena kemiripan karakteristik ibu bersalin, dan untuk lebih memudahkan dalam pencarian sampel yang terpilih.

\section{SIMPULAN}

Faktor dukungan keluarga berpengaruh secara langsung terhadap keputusan pemilihan penolong persalinan, sedangkan faktor kelas ibu hamil berpengaruh secara tidak langsung melalui dukungan keluarga terhadap keputusan pemilihan penolong persalinan. Total pengaruh kedua faktor tersebut terhadap keputusan pemilihan penolong persalinan sebesar 70,32\%. Kelas ibu hamil agar terus dilaksanakan, dan untuk meningkatkan partisipasi atau kehadiran suami/keluarga, perlu kesepakatan jadwal pelaksanaan antara petugas puskesmas dan ibu hamil. Selain itu perlu penelitian lanjutan untuk faktor serta jalur lainnya dan memperluas daerah penelitian.

\section{UCAPAN TERIMA KASIH}

Ucapan terima kasih penulis sampaikan kepada Kementerian Kesehatan Republik Indonesia atas dukungan dana untuk terselenggaranya penelitian ini, kepada Pemerintah Kabupaten Lombok Barat yang memberikan ijin pelaksanaan, kepada Kepala Dinas Kesehatan Kabupaten Lombok Barat, Kepala Puskesmas Gunungsari, Kepala Puskesmas Penimbung, semua rekan dan pihak yang telah membantu terselesainya penelitian ini.

\section{DAFTAR PUSTAKA}

1. Kementerian Kesehatan RI. Buku Saku MDGs. Jakarta; 2011a.

2. Dikes NTB. Profil Dinas Kesehatan Provinsi NTB Tahun 2010. Mataram-NTB; 2011.

3. Depkes RI. Buku Pedoman Pengenalan Tanda Bahaya Pada Kehamilan, Persalinan dan Nifas. Jakarta: Depkes RI; 2006.

4. Dikes NTB. Strategi AKINO (Angka Kematian Ibu Menuju Nol). Mataram-NTB; 2010.

5. Puskesmas Gunungsari. PWS KIA Puskesmas Gunungsari tahun 2012-2013. Gunungsari-Kabupaten Lombok Barat; 2012-2013.

6. Puskesmas Penimbung. PWS KIA Puskesmas Penimbung tahun 2012-2013. Gunungsari-Kabupaten Lombok Barat; 2012-2013.

7. Notoatmodjo, S. Promosi Kesehatan dan Perilaku Kesehatan. Jakarta: Rineka Cipta; 2012.

8. Karjono, M. Faktor-faktor yang Berhubungan dengan Keputusan Memilih Penolong Persalinan pada Ibu Hamil di wilayah Kerja Puskesmas Taliwang Kabupaten Sumbawa Barat. (tesis). Denpasar: Program Pascasarjana Universitas Udayana; 2013.

9. Lwanga, S.K and Lemeshow, S. Sample Size Determination in Health Studies. Geneva. WHO; 1997.

10. Sugiyono. Metode Penelitian Administrasi. Bandung: Alfabeta; 2005.

11. Ali-Muhidin, S., dan Abdurahman, M. Analisis Korelasi, Regresi, dan Jalur Dalam Penelitian (Dilengkapi Aplikasi Program SPSS). Bandung: Pustaka Setia; 2007.

12. Wahana Komputer. Pengembangan Analisis Multivariate. Edisi Pertama. Jakarta: Salemba Infotek; 2005.

13. Latifah-Amilda, N., Palarto, B. Faktor-faktor yang Berhubungan dengan Pemilihan Pertolongan Persalinan oleh Dukun Bayi. Program Pendidikan Sarjana Kedokteran Fakultas Kedokteran Universitas Diponegoro.[internet] 2010, [dikutip pada 13 Oktober 2013]. Available from: http:// eprints.undip.ac.id/23628/1/Nur_Latifah.pdf.

14. Armstrong, A. The Impact of Traditions and Traditional Birth Attendants on Maternal Mortality: A Case. Department of International Affairs. Thesis Advisor: Dr. Melinda Cain. Committee Members: Dr. Elisabeth Root \& Vicki Hunter. University of Colorado Study of Nyakayojo sub-County, Mbarara District, Uganda; 2011.

15. Pendit, U. Ragam Metode Kontrasepsi. Jakarta: Buku Kedokteran EGC; 2007.

16. Dadang, R. "Perilaku Ibu Bersalin dalam Memilih Penolong Persalinan di Kabupaten Sumedang" (thesis), Universitas Gadjah Mada.[internet] 2002,[dikutip pada 13 Maret 2014]. Available from: URL: http://etd.ugm. ac.id/index.php?mod= penelitian_detail\&sub=Penelitian Detail\&act $=$ view \&typ $=$ html\&buku_id $=20403 \&$ obyek_ $\mathrm{id}=4$

17. Sodikin, Emilia, O., dan Koentjoro. Determinan Perilaku Suami yang Mempengaruhi Pilihan Penolong Persalinan Bagi Istri. Sodikin, Ova Emilia, Koentjoro.2009. Fakultas Ilmu Kesehatan Universitas Muhammadiyah Purwokerto. Program Magister Ilmu Kesehatan Ibu dan Anak-Kesehatan Reproduksi Universitas Gadjah Mada Yogyakarta. Fakultas Psikologi Universitas Gadjah Mada Yogyakarta. Berita Kedokteran Masyarakat No.25 Nomor 1 Maret 2009. [internet] 2009, [dikutip pada 12 Oktober 2013]. Available from: URL: http://repository.usu.ac.id/ bitstream/123456789/14729/1/08E00942.pdf 
18. Murdiningsih. Hubungan Antara Faktor Ibu, Fasilitas Pelayanan dan Dukungan Orang Lain dengan Pemilihan Penolong Persalinan di Wilayah Kerja Puskesmas Gandus Kecamatan Gandus Palembang, tahun 2000. Perpustakaan Universitas Indonesia >> UI - Tesis (Membership) Deskripsi Dokumen: http://lontar.ui.ac.id/opac/ui/detail. jsp?id=71709\&lokasi=lokal.[internet] 2000, [dikutip pada 11 Maret 2014]. Available from: URL: http://www. google.com/\#q=pengaruh+dukungan+keluarga + terha dap+pemilihan+penolong+persalinan

19. Depkes RI. Pedoman Pelaksanaan Kelas Ibu Hamil. Jakarta; 2009.

20. Aprima-Sari, D. Faktor-Faktor yang Berhubungan dengan Keikutsertaan Ibu dalam Kelas Ibu Hamil di Puskesmas Air Dingin Padang Tahun 2013. Karya Tulis Ilmiah, Juli 2013. Prodi D III Kebidanan Stikes Mercubaktijaya Padang. [internet] 2013, [dikutip pada 13 Oktober 2013]. Available from: URL: http://midwifedilla.wordpress.com/2013/09/28/ faktor-faktor-yang-berhubungan-dengan-keikutserta an-ibu-dalam-kelas-ibu-hamil-di-puskesmas-air-dinginpadang-tahun-2013/
21. Kartini, Hubungan Kelas Ibu Hamil terhadap pemilihan penolong persalinan di Puskesmas Ambal I Kabupaten Kebumen tahun 2011. Deskripsi. http://lontar.ui.ac.id/ opac/themes/libri2/detail.jsp?id=20321575\&lokasi= lokal Perpustakaan Universitas Indonesia >> UI - Skripsi (Open). [internet] 2011, [dikutip pada 16 Oktober 2013]. Available from: URL: http://www.google. com/\#q=KELA S+IBU+HAMIL+TERHADAP+PENOLONG+PERSALI NAN+.

22. Puspitasari, L. Gambaran Pelaksanaan Kelas Ibu Hamil Di Puskesmas Bangetayu Kota Semarang. Fakultas Kesehatan Masyarakat Universitas Diponegoro. Jurnal Kesehatan Masyarakat. 2012; 1(2): 1054-1060.

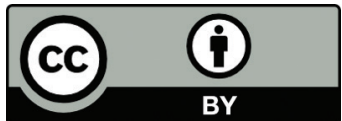

This work is licensed under a Creative Commons Attribution 